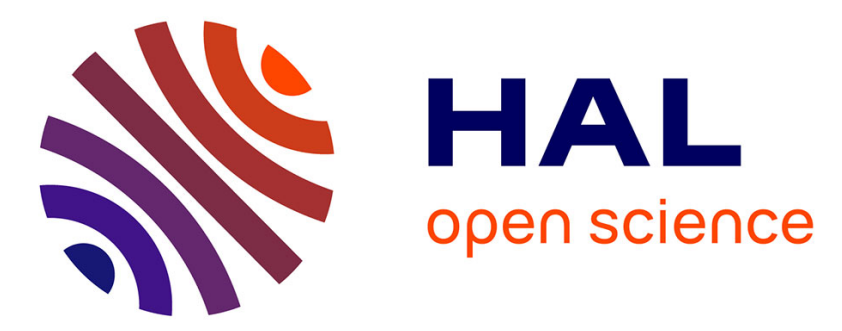

\title{
The oldest representative of the Trichomyiinae (Diptera:Psychodidae) from the Lower Cenomanian French amber studied with phase-contrast synchrotron X-ray imaging

\author{
Malvina Lak, Dany Azar, André Nel, Didier Neraudeau, Paul Tafforeau
}

\section{To cite this version:}

Malvina Lak, Dany Azar, André Nel, Didier Neraudeau, Paul Tafforeau. The oldest representative of the Trichomyiinae (Diptera:Psychodidae) from the Lower Cenomanian French amber studied with phase-contrast synchrotron X-ray imaging. Invertebrate Systematics, 2008, 22 (4), pp.471-478. 10.1071/IS08008 . insu-00339262

\section{HAL Id: insu-00339262 \\ https://hal-insu.archives-ouvertes.fr/insu-00339262}

Submitted on 17 Nov 2008

HAL is a multi-disciplinary open access archive for the deposit and dissemination of scientific research documents, whether they are published or not. The documents may come from teaching and research institutions in France or abroad, or from public or private research centers.
L'archive ouverte pluridisciplinaire HAL, est destinée au dépôt et à la diffusion de documents scientifiques de niveau recherche, publiés ou non, émanant des établissements d'enseignement et de recherche français ou étrangers, des laboratoires publics ou privés. 
Invertebrate Systematics has been given the file number IS08008

\title{
The oldest representative of the Trichomyiinae (Diptera: Psychodidae) from the Lower Cenomanian French amber studied with phase contrast synchrotron $X$-ray imaging
}

Malvina Lak ${ }^{\mathrm{A}, \mathrm{B}}$, Dany Azar ${ }^{\mathrm{C}, \mathrm{E}}$, André Nel ${ }^{\mathrm{D}, \mathrm{E}}$, Didier Néraudeau ${ }^{\mathrm{A}}$ and Paul Tafforeau $^{\mathrm{B}}$

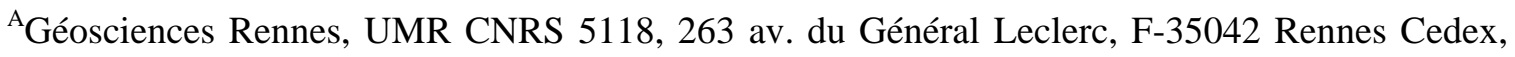
France.

${ }^{\mathrm{B}}$ European Synchrotron Radiation Facility, 6 rue Jules Horowitz, BP 220, F-38043 Grenoble Cedex 9, France.

${ }^{\mathrm{C}}$ Lebanese University, Faculty of Sciences II, Department of Biology, Fanar - Matn - P. O. box 26110217, Lebanon.

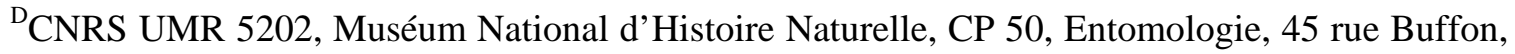
F-75005 Paris, France.

${ }^{\mathrm{E}}$ Corresponding authors. Emails: azar@mnhn.fr, anel@mnhn.fr

\section{Running title:}

\section{The oldest Trichomyiinae in Cretaceous French amber}

\begin{abstract}
Trichomyia lengleti sp. nov., is described from the Lower Cenomanian amber of La Buzinie, Charente (SW France) from a piece of fully opaque amber. The Upper Albian Trichomyia swinhoei Cockerell, 1917 is transferred from the Trichomyiinae to the Sycoracinae incertae sedis stat. nov. T. lengleti is the oldest representative of the subfamily Trichomyiinae, supporting at least a Cretaceous diversification for the Psychodidae. The discovery of this fossil fly and its study thanks to propagation phase contrast synchrotron X-ray imaging improves our knowledge of the biodiversity and the historical evolution of psychodoid flies. A check list of fossil trichomyiine species is given.
\end{abstract}


Additional keywords: Diptera, Psychodidae, Trichomyiinae, Cretaceous amber, Charente, SW France, synchrotron, phase contrast.

\section{Introduction}

Psychodid flies are relatively well represented in the fossil record (Evenhuis 1994; Azar et al. 1999; 2003; 2007a; 2007b; Azar and Nel 2002; 2003; Azar and Ziadé 2005; Nel et al. 2002; Ansorge 1994; 1996; Wagner 2002; 2006). Their oldest definitive known fossil is from the Liassic (Ansorge 1994) but their occurrence could be as old as Triassic with Triassopsychoda olseni Blagoderov \& Grimaldi, 2007 (tentatively included in ?Psychodidae), (Fraser et al. 1996; Blagoderov et al. 2007).

Trichomyiinae Tonnoir, 1922 is a subfamily of short-legged psychodid having the wing radial sector with only one vein between radial and medial forks. The monospecific Cenozoic genus Eatonisca Meunier, 1905 is characterized by a very particular wing venation. The other Cenozoic genus Eotrichomyia Nel et al., 2002 has the same wing venation as Trichomyia, but is characterized by male genitalia with stylus bearing a sharp spine as in Sycorax (Sycoracinae). Recent representatives and remaining fossils are all included in Trichomyia Haliday, 1839. As a whole this genus embraces a wide range of structures that imposed the creation of different subgenera (Duckhouse 1965, 1978, 1980; Bravo 1999, 2001, etc.). Several other extant genera were created within Trichomyiinae like Diplonema Loew, 1845, Lepria Enderlein, 1936, and Eubonetia Vargas \& Najera, 1953, but Satchell (1956) sank them in Trichomyia. The genus Phalaenomyia Loew, 1844 originally proposed without included species is considered by all the workers as a nomen nudum.

Duckhouse (1965) concluded that two or more groups are at present intermingled under Trichomyia, but he considered that it would be premature to form new genera. Nevertheless he subdivided the Trichomyiinae into two groups A and B based on antenna and palp structures. 
Sycoracinae were first classified within the subfamily Trichomyiinae but Edwards (1929) recognized the difference between Sycorax and Trichomyia and suggested that Sycorax should be classified in a separate tribe of the Trichomyiinae or preferably as a separate subfamily. Jung $(1954,1956)$ recognized a separate subfamily for Sycorax, but thereafter Jung (1958) and Hennig (1972) reverted to the single subfamily Trichomyiinae. For Duckhouse (1972), Vaillant (1978) and Wagner (1997), Sycoracinae is considered as a separate subfamily.

The oldest fossil described in the subfamily Trichomyiinae is Trichomyia swinhoei Cockerell, 1917 from the Myanmar Lower Cretaceous (Upper Albian) amber, but this specimen was badly drawn and Cockrell's (1917) description was very succinct and insufficient for an accurate attribution of this fossil. We transfer below Trichomyia swinhoei Cockerell, 1917 from the Trichomyinae to the Sycoracinae. Thus the current oldest published representative of the subfamily Trichomyiinae (Eotrichomyia electronica Nel et al., 2002) is from the Lower Eocene amber of the Paris Basin, Oise, France (Nel et al. 2002), but this subfamily occurs in the Turonian amber of New Jersey and the Upper Cretaceous amber of Myanmar (Azar pers. obs.). We describe herein a new Trichomyia species, from the Lower Cenomanian amber discovered at La Buzinie, in Charente, south-western France (Perrichot et al. 2007a, 2007b) and assess its age in relation to other Trichomyiinae. We used new Synchrotron X-ray imaging techniques (Tafforeau et al. 2006; Lak et al. 2008) that have enabled the discovery, imaging and 'virtual' extraction of the specimen from a totally opaque piece of amber

\section{Material and methods}

The amber containing the Trichomyiinae has been collected in the mid part of the Lower Cenomanian series of La Buzinie road works (Angoulême area, Charente, SW France) (Perrichot et al. 2007b), in the B2 lithological subunit sensu Néraudeau et al. (1997). The amber pieces collected in this subunit are more or less opaque, so the specimen has been detected and 3D-reconstructed using phase contrast X-ray synchrotron imaging according to the protocol published in Lak et al. (2008). All the experiments were performed at the ESRF - Grenoble (France) on the Beamline ID19. The microradiograph of the fossil fly 
being not sufficiently accurate to describe the specimen precisely; therefore the following description is based on a 3D-reconstruction, obtained by local propagation phase contrast microtomography (Tafforeau et al. 2006, Lak et al. 2008). The parameters of the scan were the following: monochromatic beam set at an energy of $20.5 \mathrm{keV}$ using a multilayer monochromator, $100 \mathrm{~mm}$ of propagation distance between the sample and the detector, $25 \mu \mathrm{m}$ thick YAG scintillator screen, isotropic voxel size of $1.4 \mu \mathrm{m}, 1500$ projections of 0.2 s each taken over 180 degrees. After tomographic reconstruction and 8 bits conversion, the volume was segmented in 3D using the software VGStudioMax 1.2.1 (Volume Graphics, Heidelberg, Germany), in order to virtually extract the specimen from the opaque amber. We could have a vision of the rotating fossil in order to examine very minute structures, such as the apical flagellomeres, the pattern of the dorsal setae, and the genitalia.

We follow the wing venational nomenclature of McAlpine (1981), with the following abbreviations: h, humeral vein; Sc, subcosta; R1, R2, R3, R4+5, radial veins; M1, M2, M3, median veins; CuA1, CuA2, cubital veins; A1, anal vein; r-m, radialmedian cross-vein.

\section{Systematic palaeontology}

Family PSYCHODIDAE Newman, 1834

Subfamily TRICHOMYIINAE Tonnoir, 1922

Genus Trichomyia Haliday (in Curtis 1839)

Type species. Trichomyia urbica Haliday, 1939 by monotypy.

Trichomyia swinhoei Cockerell, 1917

Material. Holotype In.19101, Natural History Museum, London, UK.

Type locality and horizon. Late Albian, Burmese amber, Myanmar. 


\section{Discussion}

The reexamination of this fossil material in the Natural History Museum (London) by one of us (DA) and by Derek A. Duckhouse, indicates that this specimen is definitely not a Trichomyiinae but a Sycoracinae as its CuA2 is rather short as in all known sycoracine flies (pers. obs.; and Duckhouse pers. comm. to DA). We transfer Trichomyia swinhoei Cockerell, 1917 from the Trichomyiinae to the Sycoracinae incertae sedis stat. nov. Its detailed redescription will be done in another paper.

\section{?Trichomyia lengleti, sp. nov.}

(Plate 1, Figs 1-3)

Material. Holotype BUZ 2.7 (female), from the collection of T. Lenglet, deposited in the Muséum National d’Histoire Naturelle, Département Histoire de la Terre, Paris, France. All the tomographic data as well as a surface model of the specimen are available upon request to the first author, and will be deposited in the public palaeontological database project of the ESRF when available. Reference 3D prints of the extracted specimens are deposited in the Muséum National d'Histoire Naturelle (Paris, France), in the Géosciences laboratory (Rennes, France), and at the ESRF (Grenoble, France).

Etymology. The species name is dedicated to Mr. Thierry Lenglet, who discovered the type specimen and donated it to the MNHN.

Type locality and horizon. Lower Cenomanian (subunit B2 sensu Néraudeau et al. 1997) of La Buzinie, Charente, SW France (Perrichot et al. 2007b).

\section{Diagnosis}

Head with well-developed vertex puffed out behind antenna; antenna with 15 flagellomeres bearing well-developed digitiform and sigmoid ascoids, flagellomeres 12 to 15 gradually reduced with the last one extremely reduced and drop-like; wing venation of 
Trichomyia-type with CuA2 elongated and Rs separated from R1 at the same level where Sc meets with R1, and beyond fork of M into M1+2 and M3.

\section{Description}

Head with well-developed vertex puffed out behind antenna; eyes elliptical, $148 \mu \mathrm{m}$ of large diameter and $107.5 \mu \mathrm{m}$ of small diameter; antenna $617 \mu \mathrm{m}$ long, with 15 flagellomeres, viz. 13 of normal size, the $14^{\text {th }}$ reduced and the $15^{\text {th }}$ (apiculus) very reduced and drop-like (Pl. 1, Fig. 1A); first flagellomere the longest, $42.5 \mu \mathrm{m}$, nearly 1.5 times as long as each of following ten flagellomeres; flagellomeres 2 to 11 pyriform and of nearly same length $38 \mu \mathrm{m}$ long; flagellomeres 12 and 13 of equal length and slightly shorter than the preceding, $30 \mu \mathrm{m}$ long each; flagellomere 14 well reduced and shorter than half of flagellomere 12 or $13,17 \mu$ m long, bearing the terminal flagellomere apiculus which is much reduced and drop-like; scape subspherical, nearly $34 \mu \mathrm{m}$ long and $34 \mu \mathrm{m}$ wide; pedicel subspherical, about $46.8 \mu \mathrm{m}$ long and $38.3 \mu \mathrm{m}$ wide; flagellomeres 1-6 with well-developed, digitate, and sigmoid ascoids in their ventral sides (Fig. 1B, 1C); maxillary and labial palps not visible.

Wing $1011 \mu \mathrm{m}$ long, $393 \mu \mathrm{m}$ wide (Pl. 1, Fig. 2); humeral vein (h) reaching costal margin at $129 \mu \mathrm{m}$ from wing base; subcostal vein Sc distally fused with R1 in a strong angle, $337 \mu \mathrm{m}$ from wing base, and a possible cross-vein reaching costal margin, but rather unclear character; R1 reaching costal margin $747 \mu \mathrm{m}$ from wing base; Rs separated from R1 $337 \mu \mathrm{m}$ from wing base, at same level where Sc meets with R1, and beyond fork of M into M1+2 and M3; Rs three-branched; R2 and R3 separated $708 \mu$ distally, slightly before level where R1 meets with costal margin; R2 sigmoid-shaped reaching costal margin at $921 \mu \mathrm{m}$ from wing base; R3 slightly curved at base and reaching costal margin at $989 \mu \mathrm{m}$ from wing base; R4 and R5 fused forming R4+5, $612 \mu \mathrm{m}$ long, slightly curved at its middle toward posterior side; cross-vein r-m $421 \mu \mathrm{m}$ distal of wing base; fork of M into M1+2 and M3 $112 \mu \mathrm{m}$ distal of arculus; fork of M1+2 into M1 and M2 $269 \mu \mathrm{m}$ distal of base of M1+2; M1 slightly curved; M2 slightly shorter than M1; M3 reaching wing margin at $803 \mu \mathrm{m}$ from wing base; CuA1 separating from CuA $309 \mu \mathrm{m}$ distal of wing base; CuA2 rather long, $444 \mu \mathrm{m}$ long; A1 hardly visible on right wing but reaching posterior wing margin. 
Halteres $191 \mu \mathrm{m}$ long; knob $101 \mu \mathrm{m}$ long; stem $90 \mu \mathrm{m}$ long.

Thorax nearly $358 \mu \mathrm{m}$ long, $260 \mu \mathrm{m}$ wide and $377 \mu \mathrm{m}$ high; vestiture indicated by the insertion holes of setae, grouped into three anterior longitudinal zones and two posterior zones on scutum, and two zones on scutellum (Pl. 1, Fig. 3A).

Legs short, shorter than whole body.

Abdomen $828 \mu \mathrm{m}$ long excluding genital appendages, $379 \mu \mathrm{m}$ wide; dorsal surfaces of all abdominal segments bearing few setae, indicated by insertion holes; female genital appendages: two elongated subgenital plates (Sub), $95 \mu \mathrm{m}$ long and $77 \mu \mathrm{m}$ wide; cerci (Cer) $132 \mu \mathrm{m}$ long and $77 \mu \mathrm{m}$ wide (Fig. 3B, 3C).

\section{Discussion}

As Trichomyia lengleti sp. nov. is a psychodid that has a typical trichomyiinewing structure characterized by the radial sector with only one vein between radial and medial forks, and CuA2 vein well-developed, we assign it to the Trichomyiinae.

Trichomyia lengleti differs from all the recent and fossil species belonging to Trichomyiinae in its antenna with 15 flagellomeres, while Trichomyiinae have usually antenna with 16 antennomeres, the sixteenth being very diminutive or occasionally fused to fifteenth (Duckhouse 1965). T. lengleti has flagellomeres 12 to 15 gradually reduced comparing to the more basal ones, a character inexistent in all known Trichomyiinae. Such a reduction in the terminal three or more flagellomeres is known in some Psychodinae.

Even if the antennal structures of T. lengleti are unique within the Trichomyiinae, we prefer to assign it to Trichomyia sensu lato, as the male genital appendages are not available (Eotrichomyia differs from Trichomyia in the male genital appendages), and the palps are not visible. There are not enough arguments to create a new genus. T. lengleti would fall in the group A of Duckhouse (1965) after its head with well-developed vertex, first flagellomere almost 1.5 times as long as other flagellomeres, elongate-pyriform flagellomeres, and in addition to very reduced and drop-like last flagellomere. Nevertheless T. lengleti shares with the group B of Duckhouse (1965) the well-developed digitate ascoids. 
T. lengleti is in a piece of amber which contains at least 15 well-preserved arthropods (among which Diptera notably represented by Dolichopodidae [Microphorites Hennig, 1971] and Psychodidae, Hymenoptera: Diapriidae [Lengletia chanieraudi Lak \& Nel, 2008], Blattodea, and decapod Tanaidacea), and five plant remains and microinclusions (mainly freshwater testate amoebae) (Girard pers. com.). The sedimentological characteristics of the amber deposit and the arthropod species found in other amber pieces allow interpreting the palaeoenvironement of $T$. lengleti as an estuarine forest, located at the boundary between marine and freshwater influences (Perrichot et al. 2007a, 2007b). Although the piece of amber is translucent enough to see some of the macro-inclusions, phase contrast X-ray imaging is necessary for most of them and remains preferable as a non-destructive technique.

Two other psychodoid flies, Eophlebotomus carentonensis Azar et al., 2003, and Sycorax neli Azar et al., 2007, were hitherto described from the Albian amber of Charentes, SW France (Perrichot et al. 2007a) and Lebanon respectively (Azar et al. 2003, 2007b). These discoveries confirm those from the study of the Lower Cretaceous Lebanese psychodoids about the very high diversity of this group in the Mesozoic.

\section{Acknowledgments}

We are grateful to Alain Couillard, who has discovered the amber deposit of La Buzinie and to Thierry Lenglet who collected the amber piece containing the Psychodidae. We are also grateful to the ESRF and the ID19 staff for thier help in synchrotron imaging. Lastly we thank two anonymous reviewers for their helpful criticism on the first version of the manuscript. This work is supported by the French Research Agency (ANR), project "AMBRACE" $\mathrm{n}^{\circ}$ BLAN07-1-184190. This paper is a contribution to the project "The Study of the Fossil Insects and their Outcrops: Geology of the Outcrops - Historical and Biodiversity Evolution’ accorded by the Lebanese University to DA.

\section{References}


Ansorge, J. (1994). Tanyderidae and Psychodidae (Diptera) from the Lower Jurassic of Northeastern Germany. Paläontologische Zeitschrift 68, 199-210.

Ansorge, J. (1996). Eotonisca tertiaria Meunier, 1905 (Psychodidae) aus dem Sachsischer Bernstein. Studia Dipterologica 3, 195-199.

Azar, D., Nel, A., Solignac, M., Paicheler, J-C., and Bouchet, F. (1999). New genera and species of phlebotomid and psychodid flies from the Lower Cretaceous amber of Lebanon (Insecta: Diptera: Phlebotomidae, Psychodidae). Palaeontology 42, 11011136.

Azar, D., and Nel, A. (2002). New Cretaceous psychodid flies from Lebanese amber and Santana Formation (Chapada do Araripe, Brazil). (Diptera). Annales de la Société Entomologique de France (N.S.) 38, 253-262.

Azar, D., and Nel, A. (2003). Fossil Psychodoid flies and their relation to parasitic diseases. Memorias do Instituto Oswaldo Cruz 97 (suppl. 1), 35-37.

Azar, D., Perrichot, V., Néraudeau, D., and Nel, A. (2003). New psychodid flies from the Cretaceous ambers of Lebanon and France, with a discussion about Eophlebotomus connectens Cockerell, 1920 (Diptera, Psychodidae). Annals of the American Society of America 96, 117-127.

Azar, D., and Ziadé, K. (2005). Xenopsychoda harbi, a new psychodoid fly from the Lower Cretaceous amber of Lebanon (Diptera; Psychodoidea). Comptes rendus Palevol 4, 25-30.

Azar, D., Adaymeh, C., and Jreich, N. (2007)a. Paleopsychoda zherikhini, a new Cretaceous species of moth flies from Taimyr amber (Diptera: Psychodidae: Psychodinae). African Invertebrates 48, 163-168.

Azar, D., Tahchy, A., and Perrichot, V. (2007)b. The oldest Sycoracinae (Diptera: Psychodidae) from the French Cretaceous amber. Alavesia 1, 5-10.

Bravo, F. (1999). Septemtrichomyia, subgenero novo de Trichomyiinae neotropical (Diptera: Psychodidae). Revista Brasiliera de Entomologia 43, 1-7.

Bravo, F. (2001). Opisthotrichomyia, new subgenus of Trichomyiinae (Diptera, Psychodidae) with descriptions of three new species from Brazil. Sitientibus Serie Ciencias Biologicas 1, 50-55. 
Blagoderov, V.A., Grimaldi, D.A., and Fraser, N.C. (2007). How time flies for flies: diverse Diptera from the Triassic of Virginia and early radiation of the order. American Museum Novitates 3572, 39 pp.

Cockerell, T.D.A. (1917). Fossil insects. Appendix. Annals of the Entomological Society of America 10, 19-22

Duckhouse, D.A. (1965). Psychodidae of Southern Australia, subfamilies Bruchomyiinae and Trichomyiinae. Transactions of the Royal Entomological Society of London 117, 329-343.

Duckhouse, D.A. (1972). Psychodidae (Diptera, Nematocera) of South Chile, subfamilies Sycoracinae and Trichomyiinae. Transactions of the Royal Entomological Society of London 124, 231-268

Duckhouse, D.A. (1978). Taxonomy, phylogeny and distribution of the genus Trichomyia (Diptera: Psychodidae) in Australia and New Guinea. Systematic Entomology 3, 197-243.

Duckhouse, D.A. (1980). Trichomyia species (Diptera: Psychodidae) from Southern Africa and New Zealand, with a discussion of their affinities and of the concept of monophyly in southern hemisphere biogeography. Annals of the Natal Museum 24, 177-191.

Edwards, F.W. (1929). A note on the amber moth-fly Eophlebotomus connectens Cockerell. Annals and Magazine of Natural History (10) 3, 424-425.

Evenhuis, N.L. (1994). 'Catalogue of the fossil flies of the World (Insecta: Diptera).' (Backhuys Publishers: Leiden, The Netherlands)

Fraser, N.C., Grimaldi, D.A., Olsen, P.E., and Axsmith, B. (1996). A Triassic Lagerstätte from eastern North America. Nature 380, 615-619.

Hennig, W. (1972). Insektenfossilien aus der unteren Kreide. IV. Psychodidae (Phlebotominae), mit einer kritischen Übersicht über das phylogenetische System der familie und die bisher beschriebenen Fossilien (Diptera). Stuttgarter Beiträge zur Naturkunde (B) 241, 1-69.

Jung, H.F. (1954). Einige neue mitteleuropäische Psychodiden (Diptera). Zoologischer Anzeiger 152, 16-31. 
Jung, H.F. (1956). Beiträge zur Biologie, Morphologie und Systematik der europäischen Psychodiden (Diptera). Deutsche Entomologische Zeitschrift 3, 97-257.

Jung, H.F. (1958). Psychodidae-Trichomyiinae. In: Die Fliegen der Palaerktischen Region, Linder, E. (Ed.) E. Schweizerbart’sche Verlagsbuchhandlung, Stuttgart, 116.

Lak, M., and Nel, A. (in press). A diapriine wasp (Hymenoptera: Diapriidae) from French Cretaceous amber. Geodiversitas

Lak, M., Néraudeau, D., Nel, A., Cloetens, P., Perrichot, V., and Tafforeau, P. (2008). Phase contrast X-ray Synchrotron Imaging: opening access to fossil inclusions in opaque amber. Microscopy and Microanalysis 14, (in press).

McAlpine, J.F. (1981). Morphology and terminology - adult. pp. 9-63. In: 'Manual of Nearctic Diptera. Volume 1, Monograph No. 27' (Eds J.F. McAlpine, B.V. Peterson, G.E. Shewell, H.J. Teskey, J.R. Vockeroth and D.M. Wood) pp. 1-639. (Research Branch, Agriculture Canada: Ottawa, Canada)

Nel, A., Menier, J.-J., and De Ploëg, G. (2002). The oldest representative of the Trichomyiinae from the Lowermost Eocene amber of the Paris Basin (France) (Diptera: Psychodidae). Annales de la Société Entomologique de France (N.S.) 38, 247-252.

Néraudeau, D., Thierry, J., and Moreau, P. (1997). Variations of echinoids biodiversity during the Cenomanian-Early Turonian transgressive episode in Charentes (France). Bulletin de la Société Géologique de France 168, 51-61.

Perrichot, V., Néraudeau, D., Nel, A., and De Ploëg, G. (2007a). A reassessment of the Cretaceous amber deposits from France and their palaeontological significance. African Invertebrates 48, 213-227.

Perrichot, V., Nel, A., and Néraudeau, D. (2007b). Schizopterid bugs (Insecta: Heteroptera) in mid-Cretaceous ambers from France and Myanmar. Palaeontology 50, 1367-1374.

Satchell, G.H. (1956). On the genus Trichomyia (Psychodidae) with descriptions of four new species. Proceedings of the Royal Entomological Society of London (B) 25, 147-156. 
Tafforeau, P., Boistel, R., Boller, E., Bravin, A., Brunet, M., Chaimanee, Y., Cloetens, P., Feist, M., Hoszowska, J., Jaeger, J.-J., Kay, R. F., Lazzari, V., Marivaux, L., Nel, A., Nemoz, C., Thibault, X., Vignaud, P., and Zabler, S. (2006). Applications of Xray synchrotron microtomography for non-destructive 3D studies of paleontological specimens. Applied Physics A, Materials Science \& Processing 83, 195-202.

Vaillant, F. (1978). Contribution à l'étude des Sycorax [Dipt. Psychodidae] de la France. L'Entomologiste 34, 70-77.

Wagner, R. (1997). Family Psychodidae. In: Contributions to a Manual of Palaearctic Diptera. Volume 2: Nematocera and Lower Brachycera, Papp, L. \& Darvas, B. (Eds.) Science Herald, Budapest, 205-226.

Wagner, R. (2002). A remarkable new species and genus of moth-flies (Diptera, Psychodidae, Psychodinae) from Dominican amber. [Eine bemerkenswerte neue Schmetterlingsmückenart und gattung (Diptera, Psychodidae, Psychodinae) aus dem Dominikanischen Bernstein]. Studia Dipterologica 8, 423-426.

Wagner, R. (2006). Amber Bruchomyiinae - descriptions of already known and new species, and the position of the 'subfamily' within Psychodidae (s. l.) (Diptera). Studia Dipterologica 13, 83-95. 
Appendix: List of fossil Trichomyiinae:

\begin{tabular}{|c|c|c|}
\hline Fossil taxa & Age & Deposit \\
\hline Trichomyia buceras Loew, 1845 & Holocene & $\begin{array}{l}\text { Copal of "Ostindische"= eastern } \\
\text { India or the Indonesian } \\
\text { Archipelago }\end{array}$ \\
\hline $\begin{array}{l}\text { Trichomyia antiquaria Quate, } 1961 \\
\text { Trichomyia declivivena Quate, } 1963 \\
\text { Trichomyia discalis Quate, } 1963 \\
\text { Trichomyia glomerosa Quate, } 1963 \\
\text { Trichomyia mecocerca Quate, } 1963 \\
\text { Trichomyia smithi Quate, } 1963\end{array}$ & Oligocene/Miocene & Mexican Amber \\
\hline $\begin{array}{l}\text { Eatonisca tertiaria Meunier, } 1905 \\
\text { Trichomyia brevicornis Loew, } 1850 \\
\text { Trichomyia concinna Meunier, } 1905 \\
\text { Trichomyia crassicornis Meunier, } 1905 \\
\text { Trichomyia decora Meunier, } 1905 \\
\text { Trichomyia distincta Meunier, } 1905 \\
\text { Trichomyia formosula Meunier, } 1905 \\
\text { Trichomyia longicornis Loew, } 1850 \\
\text { Trichomyia nova Meunier, } 1905 \\
\text { Trichomyia procera Meunier, } 1905 \\
\text { Trichomyia pulchra Meunier, } 1905 \\
\text { Trichomyia tenera Meunier, } 1905\end{array}$ & Eocene & $\begin{array}{l}\text { Baltic and Saxonian ambers } \\
\text { Baltic amber }\end{array}$ \\
\hline Eotrichomyia electronica Nel et al., 2002 & Lower Eocene & Oise French Amber \\
\hline Trichomyia lengleti sp. nov. & Lower Cenomanian & Charente French amber \\
\hline
\end{tabular}

N.B. Trichomyia swinhoei Cockerell, 1917 has been omitted from the list as this species undoubtedly belongs to the subfamily Sycoracinae. 


\section{Figure captions}

Pl. 1: Trichomyia lengleti sp. nov., General habitus, 3D-reconstruction using local phase contrast microtomography. $A$, dorsal view; $B$, left-side view; $C$, dorsal view. Scale bar $=500$ $\mu \mathrm{m}$, pixel size $=1.4 \mu \mathrm{m}$.

Fig. 1: Trichomyia lengleti sp. nov. A, detail of head, 15 flagellomeres visible on left antenna. Pixel size $=1.4 \mu \mathrm{m}$, scale bar $=200 \mu \mathrm{m} ; B$, detail of antennae, white arrows: sigmoidal ascoids. Pixel size $=1.4 \mu \mathrm{m}$, scale bar $=200 \mu \mathrm{m} ; C$, drawing of sigmoid ascoids on a: inner view; b: outer view; c: ventro-lateral view. Scale bar $=50 \mu \mathrm{m}$.

Fig. 2: Trichomyia lengleti sp. nov. A, left wing, missing parts of veins appear in grey dotted lines. Pixel size $=1.4 \mu \mathrm{m} ; B$, drawing of wing. Scale bar $=500 \mu \mathrm{m}$.

Fig. 3: Trichomyia lengleti sp. nov. $A$, thorax in latero-dorsal view. Scale bar $=500 \mu \mathrm{m}$, pixel size $=1.4 \mu \mathrm{m} ; B$ - $C$, details of female genitalia, respectively 3D-reconstruction and drawing, subgenital plates Sub, cerci Cer. Pixel size $=1.4 \mu \mathrm{m}$, scale bars $=200 \mu \mathrm{m}$. 